\title{
Whole class ensemble tuition - special edition
}

This volume of the British Journal of Music Education takes the form of a special edition focussing on a single issue, that of Whole Class Ensemble Tuition (WCET), a musical teaching and learning programme which has been in operation in England since a pilot programme during the academic year 2002/2003 and has been running ever since. This is not simply a local matter for a British journal, however, as there are key informants which come from careful study of this pedagogic approach. Having been running for some years now, it is timely to take a research-based look at WCET and to both investigate what is going on and, importantly, reflect on what we can learn from WCET in terms of teaching and learning music in the classroom more widely. This will, we hope, be of interest to our international audience. Devoting a whole issue to a single topic shows that we feel that this is of importance, and to this end, we have assembled a number of papers on various aspects of WCET.

The WCET programme is unusual in many ways, which the various papers in this special edition draw out. One of the key things about WCET is that there is a significant amount of government money behind it, which in these days of austerity is a significant fact in itself. Another point of interest is that this is a general music education programme, which is open to all pupils, normally in the primary school, and which involves musical learning centred around instruments. This is by no means unusual in some international contexts, but in the English situation is rather different to the ways in which music has been taught and learned according to the requirements of the National Curriculum (Department for Education, 2013), and which is normally funded out of the normal financial means of the schools in question.

In addition to researching and describing various aspects of the WCET programme, what the papers in this special edition also do, in their various ways, is to ask what can be difficult questions regarding the nature and purpose of music education. When classroom-based generalist learning of music takes place, there are a number of aspects that have given rise to questions and concerns as to what is going on. After all, as Westerlund observed:

... should we educate devoted listeners through selected classics or transmit musical hands-on knowledge for amateurs to enjoy in their future lives, or should we simply feed the existing musical institutions, symphony orchestras and the ilk, with new practitioners? (2012, p. 9)

These matters will be raised as and when teachers think about what they doing and, possibly even more importantly, why they are doing what they are doing. All of these questions, and more, are raised during the course of researching WCET, as we think about how we go from the specifics of a teaching and learning programme in England to broader questions concerning the nature of musical teaching and learning in schools and classrooms.

Although a special edition, the format of this edition of the BJME follows the same pattern as normal, with a series of research-based articles investigating and discussing WCET. Importantly, we have contributions in this volume from teachers, music educators situated at the 'sharp end' of WCET delivery, as well as from researchers looking at WCET from the perspectives of the academy. 
We open with an article by the editors, which describes the genesis, policy context and operationalisation of the WCET programme, and will hopefully set the scene for what is to come. Following this, we have an article by Susan Hallam, who has worked on and researched extensively into WCET in a number of its incarnations. She finds that success in WCET depends on a number of factors, including all school staff being committed to the programme, as well as for teachers involved to have high expectations of what can be achieved. In the next article, Martin Fautley, Victoria Kinsella and Adam Whittaker offer two conceptualisations of the ways in which WCET is both thought about and put into practice. These two conceptualisations are picked up elsewhere in this special edition, and it is to be hoped that they help both label and clarify thinking in this area.

In our next article, Barbara Johnstone finds that professional collaboration in the WCET she investigated was problematic and makes a series of recommendations suggesting what could be done about this. Following this, Anthony Anderson and Sarah Barton-Wales explore the dynamics at play in parental engagement in WCET provision, finding that motivation in the early stages of learning is influenced by levels of parental support. Our last article in this special edition is by Anna Huber, who also looks into the role of parents in WCET, finding that parents were often unsure as to what to do to help their children, except for offering general encouragement.

This range of articles from researchers, teachers and teacher-researchers moves us into close-to-practice territory, and it is to be hoped that this slightly different approach will be appreciated by the international readership of the $B J M E$ and that the music education programme described herein will give pause for reflection as to the nature of teaching and learning music in various countries in which this journal is being read across the globe.

Martin Fautley and Alison Daubney

BJME editors

\section{References}

DEPARTMENT FOR EDUCATION. (2013) National curriculum in England: Music programmes of study. London: Department for Education.

WESTERLUND, H. (2012) What can a reflective teacher learn from philosophies of music education. In C. Philpott \& G. Spruce (eds.), Debates in Music Teaching (pp. 9-19). Abingdon: Routledge.

Cite this article: Fautley M and Daubney A (2019). Whole class ensemble tuition - special edition. British Journal of Music Education 36, 221-222. https://doi.org/10.1017/S0265051719000329 